\title{
BIROKRATISASI HAM PASCA REFORMASI MELALUI PEMBENTUKAN KEMENTERIAN URUSAN HAM DAN PENGUATAN KOMNAS HAM
}

\author{
Arasy Pradana A Azis \\ Bidang Hukum dan HAM Pengurus Besar Himpunan Pelajar Mahasiswa Indonesia Gorontalo \\ J1. Salemba Tengah No. 29, Paseban, Senen, Jakarta Pusat, 10440 \\ Email: arasyaziz@gmail.com
}

\begin{abstract}
The Reformation then became a momentum for improving the issues of upholding human rights in Indonesia, where human rights matters formally entered into the division of power. On the one hand, for the first time, a ministry was formed specifically to deal with human rights matters. While outside the executive body, Law No. 39 of 1999 strengthens the position of the National Commission of Human Rights which has actually been established since 1993. This phenomenon then raises a problem statement, on how bureaucratization of human rights after Reformation is manifested through the establishment of the National Human Rights Commission and the Ministry of Human Rights. It was found that each institution gained legitimacy from political dynamics in a more democratic public space. Between the state ministries for human rights and the National Commission of Human Rights, the principle of check and balances was carried out in their role as an organ of the Indonesian bureaucracy. On the one hand, the state minister for human rights is an extension of the executive's hand in managing human rights matters. As a counterweight, the National Human Rights Commission carries out the role of the state auxiliary bodies to monitor the government's human rights work.

Keywords: Politic of Law, Bureaucratization, Human Rigths, Ministry of Law and Human Rights Affairs, National Commission of Human Rights.
\end{abstract}

\begin{abstract}
ABSTRAK
Peristiwa Reformasi menjadi momentum perbaikan urusan penegakan HAM di Indonesia, di mana urusan HAM secara formal masuk ke dalam pembagian kekuasaan negara. Di satu sisi, untuk pertama kalinya dibentuk satu kementerian yang secara khusus menangani urusan HAM. Sementara di luar lembaga eksekutif, Undang-Undang Nomor 39 Tahun 1999 menguatkan kedudukan Komisi Nasional Hak Asasi Manusia yang sejatinya telah terbentuk sejak tahun 1993. Fenomena ini kemudian menimbulkan satu rumusan permasalahan, yaitu bagaimana birokratisasi urusan HAM pasca reformasi termanifestasi melalui pembentukan Komnas HAM dan kementerian urusan HAM. Ditemukan bahwa masing-masing lembaga memperoleh legitimasi dari dinamika politik di ruang publik yang lebih demokratis. Antara kementerian negara urusan HAM dan Komnas HAM kemudian menjalankan prinsip check and balances dalam menjalankan perannya sebagai organ birokrasi Indonesia. Di satu sisi, kementerian negara urusan HAM merupakan perpanjangan tangan eksekutif untuk mengurus urusan HAM. Sebagai penyeimbang, Komnas HAM menjalankan peran sebagai state auxiliary bodies guna mengawasi kinerja HAM pemerintah.
\end{abstract}

Kata Kunci: Politik Hukum, Birokratisasi, Hak Asasi Manusia, Kementerian Urusan HAM, Komnas HAM. 


\section{PENDAHULUAN}

Pada kurun waktu tertentu, Indonesia pernah mengalami masa-masa suram di mana urusan Hak Asasi Manusia (HAM) dinomor duakan, dan pada taraf tertentu, dikesampingkan oleh rezim yang berkuasa dalam pembentukan dan pelaksanaan kebijakannya. Melalui lengan birokrasi, pelanggaran oterjadi terang-terangan terhadap hak-hak yang notabene bersifat fundamental, baik hak hidup, ekonomi dan politik. Dilakukan secara terstruktur, sistematis dan masif oleh aparat negara yang justru diidealkan menjadi pelindung bagi rakyat Indonesia. Persebaran peristiwanya tidak hanya terkonsentrasi di ibukota, melainkan secara merata terjadi di berbagai pelosok nusantara. Baik dalam skala kecil yang menimbulkan korban individual, hingga genosida terhadap suatu kelompok masyarakat.

Ironisnya, pelanggaran-pelanggaran tersebut tampak legal apabila kita menengok konstruksi kehidupan bernegara yang tercantum dalam Undang-Undang Dasar 1945. Konstitusi yang dirumuskan pada tahun 1945 ini, melewati fase keberlakuan selama pemerintahan Orde Lama dan Orde Baru, hingga mulai diamandemen pada tahun 1999. Pada periode tersebutlah, situasi anomie atas penegakan HAM terjadi secara vulgar. Baik pemerintahan Orde Lama maupun Orde Baru menampilkan paras yang hampir serupa. Rezim Orde Lama tercatat pernah melakukan pembubaran Partai Masyumi dan Partasi Sosialis Indonesia (PSI) secara sepihak tanpa melalui prosedur peradilan yang fair. ${ }^{1}$ Sementara itu, catatan pelanggaran HAM oleh Orde Baru meliputi beberapa kasus yang lebih beragam dan notable, diantaranya kasus pembantaian massal sebagai respon peristiwa Gerakan 30 September (G30S) pada kurun 1966-1967, kasus Penembak Misterius (Petrus), peristiwa Talangsari, pembredelan sejumlah media secara sepihak, serta kematian dan penghilangan paksa yang terjadi selama periode reformasi

Apabila ditilik, amat sedikit pasal-pasal yang secara eksplisit mengatur perihal HAM di dalam UUD 1945. Dalam proses perumusan UUD 1945, masalah HAM memang sempat menjadi isu krusial dalam alam perdebatan para pendiri negara. Panitia 9, selaku forum tidak resmi yang bertugas merumuskan naskah undang-undang dasar dalam Panitia Persiapan Kemerdekaan

\footnotetext{
${ }^{1}$ Pembubaran Partai Masyumi dan PSI didasari oleh tuduhan keterlibatan keduanya dalam pemeberontakan PRRI/Permesta. Pemerintahan Orde Baru kemudian membentuk Keppres Nomor 200 Tahun 1960 dan Keppres Nomor 201 Tahun 1960 yang berisi perintah pembubaran masing-masing partai. Di dalam aturan yang sama, pemerintah menegaskan akan menetapkan keduanya sebagai partai terlarang apabila perintah pembubaran sendiri tidak dipatuhi. Menurut Ali Safa'at, bentuk perintah pembubaran oleh presiden tanpa melalui lembaga peradilan sangat membahayakan kehidupan demokrasi. Partai yang berkuasa dapat memanfaatkannya untuk memburbarkan lawan politiknya. Lihat Safa'at, MA, (2011), Pembubaran Partai Politik: Pengaturan dan Praktik Pembubaran Partai Politk dalam Pergulatan Republik, Jakarta: Rajawali Pers, hlm 332-333.
} 
Indonesia (PPKI) menjadi terbelah dalam dua kubu. Sebagian diantaranya, seperti Soepomo, memandang bahwa integrasi HAM dalam konstitusi tidak dibutuhkan dan justru bertentangan dengan pandangan bernegara yang hendak dibangun. Mereka menilai, kecenderungan individualis dalam konsep HAM negara-negara Barat adalah bentuk pelencengan atas sifat gotong royong masyarakat Indonesia. Soepomo mengajukan konsep negara kekeluargaan, yang memandang jalannya negara ibarat jalannya sebuah keluarga besar dengan pemerintah berperan sebagai orang tua.

Pandangan ini kemudian ditentang oleh faksi dengan Mohammad Hatta dan Mohammad Yamin sebagai juru bicara utama. Hatta telah mengingatkan bahwa apabila hakhak berserikat, berkumpul dan mengeluarkan pendapat tidak dijamin di dalam konstitusi, Indonesia akan jatuh kepada bentuk negara kekuasaan. Hak-hak tersebut dinilainya penting sebagai sarana kontrol atas jalannya penyelenggaraan negara oleh pemerintah. Akhirnya sebagai bentuk kompromi, lahirlah Pasal 28 yang mengatur kemerdekaan berpendapat. $^{2}$

Kekhawatiran Hatta atas ketiadaan pencantuman klausul mengenai hak asasi pada akhirnya benar-benar mewujud ketika pemerintahan yang sempat berlangsung demokratis pada kurun 1945-1959 berakhir dengan kebangkitan rezim Orde Lama, dan kemudian digantikan Orde Baru. Tindakan pertama yang dilakukan oleh Orde Lama sendiri adalah pembubaran Dewan Konstituante, yang notabene dipilih secara demokratis guna menyusun konstitusi baru bagi negara Indonesia. ${ }^{3}$ Sebuah bentuk pemberangusan terang-terangan atas perwakilan pendapat rakyat Indonesia. Keputusan yang dituangkan dalam Dekrit Presiden 5 Juli 1959 tersebut juga mencakup penetapan keberlakuan kembali UUD 1945, yang pada masa itu telah dilengkapi oleh bagian penjelasan yang dirumuskan Soepomo.Rezim ini, ironisnya, juga lazim dikenal sebagai Demokrasi Terpimpin.

Orde Baru yang kemudian menggantikan Orde Lama bahkan melakukan tindakan pelanggaran HAM yang lebih variatif. Analisis Saya Sasaki Shiraishi menyatakan bahwa Soeharto cenderung menjalankan pemerintahannya dalam kerangka negara integralistik yang pernah dirumuskan oleh Soepomo. Dalam kerangka tersebut, Soeharto menempatkan diri sebagai bapak bagi seluruh bangsa Indonesia. Setiap tindakan masyarakat yang dianggap menyeleweng dianggap sebagai bentuk ketidak patuhan seorang anak,

\footnotetext{
${ }^{2}$ Pasal tersebut berbunyi: "Kemerdekaan berserikat dan berkumpul, mengeluarkan pikiran dengan lisan dan tulisan dan sebagainya ditetapkan dengan Undang-undang."

${ }^{3}$ Dekrit Presiden 5 Juli 1959 dalam Said, MM, (1951), Pedoman Untuk Melaksanakan Amanat Penderitaan Rakjat Djilid I, Surabaya: Penerbit Permata, hlm 45.
} 
dansepantasnya untuk dikenakan hukuman oleh Soeharto yang menjalankan peran sang bapak. $^{4}$

Sekalipun Orde Lama dan Orde Baru secara legal maupun politik mendaku mendasarkan diri pada UUD 1945, namun penyimpangan-penyimpangan terus menerus terjadi. Bagian Penjelasan yang secara tegas menyatakan bahwa Indonesia merupakan negara hukum (rechstaat) dan bukan negara kekuasaan (machstaat) tidak mewujud dalam tataran praktik. Tampak tiada upaya untuk memastikan prinsip-prinsip negara hukum, dimana penegakan HAM sebagai salah satunya, dijalankan dengan baik.

Ketiadaan klausul mengenai HAM dan karakteristik kepemimpinan masing-masing rezim yang otoriter dapat ditebak berimplikasi pada jalannya birokrasi Indonesia pada masa tersebut. Birokrasi, menurut Tri Hayati, merupakan "suatu tipe organisasi yang melaksanakan tata kerja yang telah ditetapkan oleh peraturan perundang-undangan dan bertugas melakukan pelayanan publik (public service) serta dilaksanakan dengan sepenuhnya (dengan sense of belonging dan sense of responsibility)." ${ }^{5}$ Dengan kata lain, terdapat suatu relasi yang saling menjalin antara birokrasi dan peraturan perundangundangan. Birokrasi memperoleh atribusi tugas, fungsi dan kewenangannya dari hukum positif. Sementara itu, hukum sendiri juga perlu dipandang sebagai produk politik, dimana hukum positif mencerminkan watak politik suatu zaman. ${ }^{6}$ Dengan demikian, jalannya birokrasi tak lain merupakan manifestasi dari dinamika politik. Relasi ini tidak hanya berlaku pada hal-hal yang diatur melalui hukum tertulis. Ketiadaan suatu aturan yang mengatur hal tertentu, dapat diartikan sebagai pembolehan bagi kerja birokrasi. Dengan demikian, ketika aturan tentang HAM yang diundangkan selama periode Orde Lama dan Orde Baru tiada, maka penyimpangan atas HAM dalam pelaksanaan birokrasi pada kedua kurun tersebut tidak dapat dielakkan.

Di luar sistem, fungsi kontrol tidak berjalan akibat pembatasan saluran-saluran aspirasi masyarakat. Masyarakat tidak memiliki wadah untuk menjalankan pengawasan guna memastikan hak-hak mereka terpenuhi oleh sistem, baik melalui lembaga-lembaga negara maupun pers sebagai watchdog. Birokasi, yang notabene diciptakan untuk mencapai tujuan negara, pada akhirnya justru menjauh dari kehendak untuk "melindungi segenap bangsa Indonesia dan seluruh tumpah darah Indonesia danuntuk memajukan kesejahteraan

\footnotetext{
${ }^{4}$ Shiraishi, SS, (2001), Pahlawan-pahlawan Belia: Keluarga Indonesia dalam Politik [Young Heroes: The Indonesian Family in Politics], Diterjemahan oleh Tim Jakarta-Jakarta, Jakarta: Penerbit Nalar.

${ }^{5}$ Hayati, Tri, (2012), Birokrasi dan Good Governance, Jakarta, Bahan Kuliah tidak diterbitkan, hlm 5.

${ }^{6}$ MD, MM, (1999), Pergulatan Politik dan Hukum di Indonesia, Yogyakarta: Gama Media, hlm 4.
} 
umum, mencerdaskan kehidupan bangsa dan ikutmelaksanakan ketertiban dunia."”

Harapan atas perubahan ke arah birokrasi yang lebih humanis kemudian muncul seiring dengan merekahnya tuntutan reformasi pada medio akhir tahun 90an, lepas 30 tahun pemerintahan Orde Baru. Krisis ekonomi menjadi katalis bagi kejenuhan masyarakat atas watak otoriter Orde Baru, dan mulai membangkitkan gerakan mahasiswa. ${ }^{8}$ Bersama gerakan sipil yang terbentuk di luar rezim berbentuk partai dan lembaga swadaya masyarakat, mereka bahu membahu memunculkan tuntutan demokratisasi sistem politik, penguatan HAM dan good governance. 9 Akhirnya, pada 21 Mei 1998, Soeharto resmi meletakkan jabatan sebagai presiden Indonesia.Pergantian rezim yang berlangsung secara cepat drastis ini memberikan ruang bagi penegakan HAM dan reformasi birokrasi sekaligu. Telah disebutkan sebelumnya bahwa keduanya merupakan dua tema unggulan yang dituntut dalam pelaksanaan reformasi. Kedua tema tersebut dapat dilihat sebagai satu kesatuan tuntutan komitmen, dimana birokrasi perlu dijalankan dengan memerhatikan prinsip-prinsip HAM; sesuatu yang selama sejarah pemerintahan Indonesia sebelumnya absen dan cenderung diabaikan.

Berturut-turut, MPR mengundangkan TAP MPR Nomor XVII/MPR/1998 tentang Hak Asasi Manusia. ${ }^{10}$ Kantor kepresidenan dibawah pemerintahan BJ Habibie meresponnya dengan membentuk Keputusan Presiden (Keppres) Nomor 129 Tahun 1998 tentang Rencana Aksi Nasional Hak-Hak Asasi Manusia Indonesia (RANHAM) sebagai kerangka kerja Komnas HAM. Selanjutnya, Undang-Undang Nomor 39 Tahun 1999 tentang Hak Asasi Manusia (UU HAM) pun diundangkan, sebelum akhirnya wacana ini diwujudkan dalam bentuk amandemen konstitusi sebagai produk hukum tertinggi.

\footnotetext{
${ }^{7}$ Undang-Undang Dasar Negara Republik Indonesia Tahun 1945, Bagian Pembukaan.

${ }^{8}$ Kasenda, P, (2013), Soeharto: Bagaimana Ia Bisa Melanggengkan Kekuasaan Selama 32 Tahun, Jakarta: Kompas, hlm. 15. Jelang reformasi, terjadi penurunan nilai tukar Rupiah atas Dollar Amerika Serikat (AS) secara drastis dari level Rp 4.850/US\$ pada pertengahan tahun 1997 menjadi Rp 17.000/US\$ di awal tahun 1998, menyebabkan pembengkakan hutang luar negeri dan inflasi.

${ }^{9}$ Subekti, VS, (2008), Menyusun Konstitusi Transisi: Pergulatan Kepentingan dan Pemikiran dalam Proses Perubahan UUD 1945, Jakarta: Rajawali Pers, hlm 69-74.

${ }^{10}$ Salah satu bagian menarik dari Ketetapan ini adalah sebuah klausul yang juga mengungkap "komitmen" Orde Baru yang masih muda untuk mengemukakan masalah hak asasi manusia sebagai salah satu program rezim. Dituturkan bahwa melalui TAP MPRS Nomor XIV/MPRS/1966, Panitia Ad Hoc dibentuk untuk menyiapkan Dokumen Rancangan Piagam Hak Asasi Manusia dan Hak-hak serta Kewajiban Warga Negara. Lebih lanjut, “(b)erdasarkan Keputusan Pimpinan MPRS tanggal 6 Maret 1967 Nomor 24/B/1967, hasil kerja Panitia Ad Hoc diterima untuk dibahas pada persidangan berikutnya. Namun pada Sidang Umum MPRS tahun 1968 Rancangan Piagam tersebut tidak dibahas karena "sidang lebih mengutamakan membahas masalah mendesak yang berkaitan dengan rehabilitasi dan konsolidasi nasional setelah terjadi tragedi nasional berupa pemberontakan G-30-S/PKI pada tahun 1965, dan menata kembali kehidupan nasional berdasarkan Pancasila dan Undang-Undang Dasar 1945."
} 
Euforia atas penegakan HAM ini kemudian berimplikasi pada pembentukan lembagalembaga yang secara khusus berurusan dengan HAM. Di lingkaran eksekutif, dibentuk sebuah kementerian dengan nomenklatur yang belum pernah dikenal sebelumnya. Pertama kalinya sepanjang sejarah Indonesia, pranata eksekutif menunjukkan komitmen atas HAM dalam struktur organisasinya. Hal ini mewujud dalam Keputusan Presiden Nomor 134 Tahun 1999, negara memperkenalkan Kementerian Negara Hak Asasi Manusia (Kemenag HAM). Sebelumnya, diluar kabinet negara juga menegaskan posisi kelembagaan Komnas HAM dalam struktur ketatanegaraan Indonesia, melalui sejumlah norma dalam UU HAM. Komnas HAM sendiri telah dikenal sejak tahun 1993, namun perannya kurang signifikan akibat pengaturannya yang didasarkan pada Keputusan Presiden. Hal ini memiliki konsekuensi terhadap posisinya dalam kelembagaan Indonesia.

Pada masing-masing peraturan perundangundangan telah disebutkan tugas, fungsi dan wewenang kedua lembaga terhadap penegakan HAM di Indonesia. Dengan posisinya sebagai pengemban atribusi hukum positif, maka kedudukan kementerian urusan HAM dan Komnas HAM sebagai hasil tegangan politik di seputar peristiwa reformasi merupakan sebuah keniscayaan. Berdasarkan latar belakang diatas, dapat diambil sebuah rumusan masalah yaitu bagaimana birokratisasi urusan HAM pasca reformasi termanifestasi melalui pembentukan Komnas HAM dan kementerian urusan HAM?

\section{PEMBAHASAN}

Selama periode reformasi, masalah HAM telah menjadi salah satu tuntutan utama dari ruang publik agar dipenuhi oleh negara. Hal ini sebagai akibat dari berbagai permasalahan penegakannya dalam sejarah Indonesia sebelumnya. Pengabaian HAM kerap terjadi dalam praktik birokrasi, baik selama masa Orde Lama maupun Orde Baru. Tak ayal, seiring dengan pasang naik tuntutan demokratisasi di segala lini, maka masalah HAM segera mencuat kembali. Namun sebelum lebih jauh membahas mengenai proses birokratisasi urusan HAM, perlu dibahas terlebih dahulu hubungan antara politik, hukum, dan birokrasi itu sendiri.

\section{Hubungan Politik, Hukum, dan Birokrasi}

Dalam konteks relasi antara politik dan hukum sebagai sumber legitimasi dan kewenangan birokrasi, pembentukan beragam hukum positif terkait HAM tersebut merupakan ekspresi murni dari euforia reformasi yang mengarah kepada demokratisasi. Mahfud MD dalam Politik Hukum di Indonesia berusaha menjabarkan relasi antara politik dan hukum sebagai dua variabel yang saling terikat. Asumsi dasarnya, konfigurasi politik suatu negara akan memengaruhi karakter produk peraturan perundang-undangan dari negara tersebut. Di 
dalam negara dengan pemerintahan otoriter, maka produk-produk hukumnya akan cenderung bersifat konservatif dan menindas. Di sisi lain, apabila suatu negara memiliki pemerintahan yang berkarakter demokratis, maka produk hukum yang dihasilkan akan memiliki watak reformis dan responsif. ${ }^{11}$

Reformasi dapat dikatakan merupakan momen keruntuhan bagi pemerintahan Orde Baru yang telah berkuasa selama 32 tahun. Ia menampilkan iklim politik yang membebaskan dan demokratis. Watak otoriter dari pemerintahan Soeharto segera berganti secara drastis dengan demokrasi seiring dengan tuntutam perubahan dari masyarakat di akar rumput. Krisis ekonomi yang terjadi pada detik-detik terakhir reformasi membuka mata sebagian besar orang bahwa birokrasi Orde Baru telah dijalankan dengan buruk. Salah satu bentuknya adalah korupsi yang dilaksanakan oleh kerabat dekat presiden. ${ }^{12}$ Hal ini berbanding terbalik dengan salah satu watak birokrasi Pancasila yang dirumuskan oleh Miftah Thoha. Diturunkan dari sila Kerakyatan yang Dipimpin oleh Hikmat Kebijaksanaan dalam Permusyawaratan/ Perwakilan, birokrasi Indonesia diidealkan mementingkan kepentingan bangsa dan negara di atas kepentingan individual dan golongan. ${ }^{13}$

Birokrasi Indonesia juga menghargai dan memanusiakan manusia berlandaskan persamaan derajat, hak dan kewajiban sesuai dengan prinsip Kemanusiaan yang Adil dan Beradab. ${ }^{14}$ Tegangan politik Orde Baru yang otoriter segera menemukan pembebasannya melalui momen reformasi 1998. HAM, sebagaimana otonomi daerah, pengendalian harga dan tuntutan reformasi lainnya, merupakan suara dari ruang publik yang selama ini tidak terakomodasi oleh sistem Orde Baru dan segera menemukan konteks. Pembentukan berbagai produk hukum yang berkenaan dengan HAM, sebagaimana dikarakterisasi Selznick dan Nonet, memenuhi kriteria hukum responsif yang "mengurai ketegangan." Hukum responsif, menurut keduanya "perceives sosial pressures as sources of knowledge and opportunity for self correction." ${ }^{15}$ Atau dengan kata lain, menjadikan dinamika sosial sebagai sumber inspirasi perumusan substansi hukum sekaligus koreksi diri. Absensi penghormatan atas HAM dalam dinamika hukum Indonesia pada umumnya, dan jalannya birokrasi pada khususnya, selama periode Orde Baru, segera

\footnotetext{
${ }^{11}$ MD, MM, (2011), Politik Hukum di Indonesia, Jakarta: Rajawali Pers, hlm. 22.

12 Adzkia, A, Beda Jurus Korupsi Era Soeharto dan Reformasi, diakses pada 28 Februari 2017, http://www.cnnindonesia.com/nasional/20150521153708-74-54824/beda-jurus-korupsi-era-soeharto-danreformasi/.

${ }^{13}$ Thoha, M, (2014), Birokrasi dan Dinamika Kekuasaan, Jakarta: Kencana, hlm 14.

${ }^{14}$ Ibid, hlm 13.

15 Nonet, P \& Selznick, P, (2009), Law and Society in Transition: Toward Responsive Law, London: Transaction Publisher, hlm 77.
} 
direspon dengan pembentukan produk-produk hukum yang mengembalikan kedudukan HAM.

Tegangan politik yang demokratis, diikuti dengan pembentukan peraturan perundangundangan HAM yang bersifat responsif, kemudian berimplikasi pada upaya pelembagaan birokrasi yang lebih humanis. Relasi ketiganya tak dapat dipisahkan, bahkan dapat disusun dalam bentuk piramida relasional di bawah.

Gambar 2.1

Piramida Hubungan antara Politik, Hukum dan Birokrasi

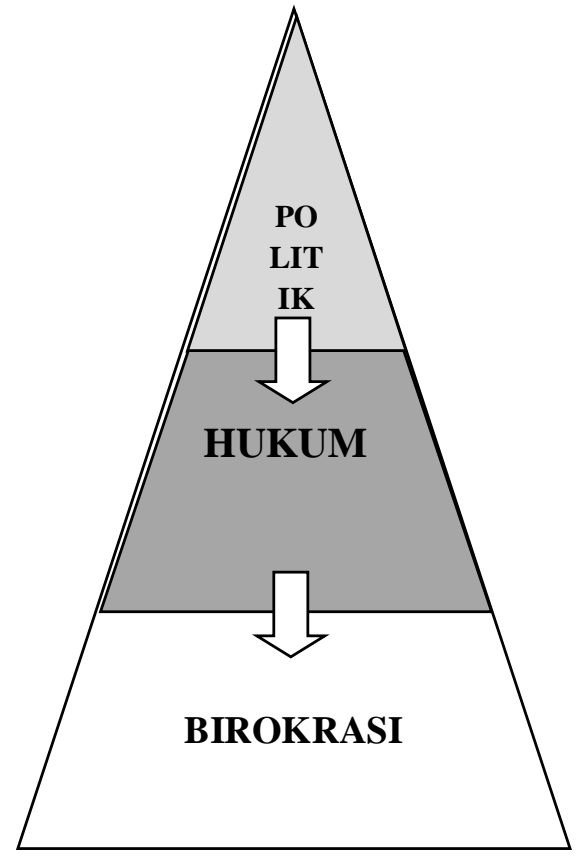

Sumber: Data Sekunder, diolah.

Birokrasi, sebagaimana dideskripsikan Tri Hayati, sebagai "suatu tipe organisasi yang melaksanakan tata kerja yang telah ditetapkan oleh peraturan perundang-undangan," maka segera tampak bahwa terdapat ketergantungan birokrasi dengan peraturan perundangundangan. Hukum positif memberi deskripsi sekaligus pembatasan-pembatasan bagi tugas, fungsi dan wewenang suatu birokrasi. Keberadaan hukum akan memastikan birokrasi bekerja sesuai koridornya, sekaligus memberikan kepastian dan perlindungan atas tindakan pelampauan kekuasaan (abuse of power), khusunya bagi masyarakat.

Hukum sekaligus menjadi jembatan bagi hubungan antara politik dan birokrasi. Dalam relasi politik-hukum Mahfudian yang menempatkan hukum sebagai variabel yang terpengaruh oleh dinamika politik suatu zaman, maka birokrasi yang memperoleh wewenang dari hukum niscaya akan terpaparpengaruh. Sistem politik yang otoriter akan melahirkan pranata-pranata birokrasi yang kaku, konservatif dan bahkan cenderung menindas. Sementara dalam alam politik yang demokratis, birokrasi juga akan turut terpapar semangat yang responsif dan menjawab permasalahan zaman. Dalam situasi kongkret, tegangan politik diturunkan dalam bentuk legitimate power. Menurut Thoha, wewenang didefinisikan berdasarkan hak-hak perogatif, obligasi dan pertanggung jawaban. Seorang birokrat dapat mendefinisikan hak untuk membuat instruksi. Sebagai timbal balik, seorang bawahan berhak meminta arahan. ${ }^{16}$ Dalam deskripsi wewenang ini, watak

\footnotetext{
${ }^{16}$ Thoha, Op.Cit., hlm 177.
} 
ideologis-politis suatu rezim dapat didefinisikan.

Kembali kepada konteks birokratisasi HAM pasca reformasi, cerminan politik demokratisasi dan penegakan HAM dengan demikian dapat ditengok pada konstruksi lembaga-lembaga yang berurusan dengan HAM. Terdapat dua lembaga yang menjadi titik fokus pada penyusunan makalah ini. Di satu sisi, terdapat Komnas HAM sebagai "lembaga mandiri yang kedudukannya setingkat dengan lembaga negara lainnya yang berfungsi melaksanakan pengkajian, penelitian, penyuluhan, pemantauan, dan mediasi hak asasi manusia."17 Namun sebelum membahas Komnas HAM, terlebih dahulu perlu dibahas sebuah pranata dengan nomeklatur yang sepenuhnya baru dalam sejarah kelembagaan negara Indonesia. Apabila kedudukan Komnas HAM dalam birokrasi masih perlu dideskripsikan lebih lanjut, pranata ini justru berada pada lingkaran inti kekuasaan birokrasi negara. Eksistensinya menunjukkan perubahan drastis atas perspektif negara terhadap urusan HAM. Lembaga tersebut adalah Kementerian Negara Urusan HAM, yang menjadi cikal bakal Kementerian Hukum dan HAM dalam beberapa kabinet Indonesia belakangan.

\section{Kelembagaan Kementerian Negara Urusan HAM dan Komisi Nasional Hak Asasi Manusia (Komnas HAM)}

Tanggal 10 November 1999 dapat dikategorikan sebagai tanggal bersejarah bagi perkembangan birokrasi di Indonesia. Pada tanggal tersebut, presiden Abdurrahman Wahid mengundangkan Keputusan Presiden Nomor 134 Tahun 1999 tentang Kedudukan, Tugas, Fungsi, Susunan Organisasi, dan Tata Kerja Menteri Negara. Meskipun hanya terdiri atas 20 pasal, namun substansi dan materi muatan yang dikandung di dalamnya mencerminkan semangat reformasi pada era tersebut. Untuk pertama kalinya, nomenklatur Kementerian Negara Urusan HAM diperkenalkan. Nomenklatur ini tidak pernah dikenal sebelumnya dalam tradisi kelembagaan kabinet di Indonesia, baik pada era Orde Lama maupun Orde Baru. Peminggiran urusan HAM ini menjadi wajar apabila mengingat ketiadaan klausul maupun bab yang komprehensif mengatur urusan HAM dalam UUD 1945.

Dalam perjalanan bangsa Indonesia, ketiadaan pengaturan di level konstitusi ini menimbulkan konsekuensi yang amat berat. Oleh Soeharto, karakter negara integralistik dikembalikan dalam praktik birokrasinya. Dengan watak politik kepemimpinan yang otoriter, integralistik dan paternalistik, ditambah ketiadaan aturan mengenai

\footnotetext{
${ }^{17}$ Undang-Undang Nomor 39 Tahun 1999 tentang Hak Asasi Manusia, Pasal 1 angka 7.
} 
perlindungan HAM, praktik birokrasi yang tidak menghormati HAM menjadi tidak terhindarkan. Selama periode kepemimpinan Soeharto, terjadi berbagai represi dengan melibatkan aparat negara yang justru diidealkan melindungi hak-hak masyarakat. Nalar kritis untuk melawan perintah-perintah yang menindas masyarakat mengalami kebuntuan.

Dalam asas struktur kelembagaan, pengenyampingan masalah HAM ini kemudian tampak pada ketiadaan kementerian urusan HAM di dalam kabinet. Pola ini telah berlaku sejak kabinet pertama pasca kemerdekaan, hingga akhir reformasi pada tahun 1998. Dalam hukum tata negara Indonesia, kewenangan tertinggi atas jalannya pemerintahan berada di tangan Presiden. ${ }^{18}$ Dalam menjalankan pemerintahan, Presiden dapat dibantu menteri-menteri dalam sebuah kabinet. Adapun pembentukan kabinet merupakan hak perogatif Presiden sepenuhnya, sebagaimana diatur di dalam Pasal 17 UUD 1945. Sehingga pembentukan, penggabungan maupun penghapusan suatu kementerian amat bergantung pada kebijaksanaan Presiden. Tentu saja, ketiadaan komitmen terhadap HAM akan tampak dalam susunan kementerian pada masing-masing rezim. Di bawah rezim yang otoriter, maka urusan dan penegakan HAM oleh birokrasi termarginalisasi.

Oleh karena itu, peristiwa reformasi benarbenar memberikan harapan bagi jalannya pemerintahan Indonesia yang lebih baik. Komitmen tersebut diaplikasikan melalui pembentukan pranata di dalam lingkaran inti eksekutif, berbentuk kementerian yang secara khusus menangani urusan HAM. Hal ini sebagaimana tercantum dalam Keputusan Presiden Nomor 134 Tahun 1999 tentang Kedudukan, Tugas, Fungsi, Susunan Organisasi, dan Tata Kerja Menteri Negara. Sebagaimana telah disebutkan sebelumnya, pejabat Presiden yang membentuk peraturan tersebut adalah Abdurrahman Wahid.

Sebagaimana disebutkan dalam Pasal 3 Keputusan Presiden Nomor 134 Tahun 1999, Kementerian Negara Urusan HAM bertugas membantu Presiden dalam menyelenggarakan urusan pemerintahan di bidang HAM. Lebih lanjut, kementerian tersebut memiliki tugas dan wewenang untuk merumuskan kebijakan pemerintah di bidang HAM, mengkoordinasikan dan meningkatkan keterpaduan penyusunan rencana dan program, serta kerja sama nasional dan internasional di bidang HAM, meningkatan peran serta masyarakat di bidang penegakan dan pencegahan pelanggaran HAM, serta menyampaikan laporan hasil

\footnotetext{
${ }^{18}$ Undang-Undang Dasar 1945, Pasal 4 ayat (1).
} 
evaluasi, saran, dan pertimbangan di bidang tugas dan fungsinya kepada Presiden. ${ }^{19}$

Dibanding Kementerian Negara HAM yang baru terbentuk pasca reformasi 1998, Komnas HAM telah lahir beberapa tahun lebih awal. Komnas HAM didirikan berdasarkan Keputusan Presiden Republik Indonesia Nomor 50 Tahun 1993 tentang Komisi Nasional Hak Asasi Manusia, yang diundangkan pada tanggal 7 Juli 1993. Keppres pembentukan Komnas HAM ditandatangani oleh Soeharto yang menjabat sebagai presiden Indonesia. Berdasarkan peraturan tersebut, pemerintah mempertimbangkan dua hal utama dibalik kebijakan pendirian Komnas HAM. Pertama, pandangan yang menghormati manusia sebagai mahluk ciptaan Tuhan, yang dianugerahi hak-hak asasi untuk dapat mengembangkan diri pribadi, peranan, maupun sumbangsih kepada masyarakat. Kedua, menghormati Piagam Perserikatan Bangsa-Bangsa dan Deklarasi Universal Hak Asasi Manusia Perserikatan Bangsa-Bangsa dalam posisi Indonesia sebagai bagian warga dunia. $^{20}$

Kegiatan Komnas HAM menurut Pasal 5 Keppres Nomor 50 Tahun 1993 terdiri atas: a) penyebarluasan wawasan nasional dan internasional mengenai HAM baik kepada masyarakat Indonesia maupun kepada masyarakat Internasional; b) pengkajian berbagai instrumen Perserikatan BangsaBangsa tentang hak asasi manusia dengan tujuan memberikan saran-saran mengenai kemungkinan aksesi dan/atau ratifikasinya; c) pemantauan dan penyelidikan pelaksanaan HAM serta memberikan pendapat, pertimbangan dan saran kepada badan pemerintahan Negara mengenai pelaksanaan HAM; serta d) mengadakan kerjasama regional dan internasional dalam rangka mengajukan dan melindungi HAM.

Apabila diperhatikan, terdapat beberapa kelemahan dalam konstruksi kelembagaan Komnas HAM berdasarkan Keppres tersebut. Meskipun ditegaskan bersifat mandiri ${ }^{21}$, posisi Komnas HAM sangat lemah terhadap Presiden. Hal ini dengan mempertimbangkan norma pembentuknya yang berupa Keppres, yang menyebabkan posisinya secara otomatis tersubordinasi oleh kekuasaan presiden. Dapat dilihat bahwa sebagian besar tugas dan wewenang yang dibabankan kepada Komnas HAM pada saat itu lebih banyak bersifat administratif dan berbentuk tindakan pencegahan. Semisal, melakukan sosialisasi wawasan HAM kepada masyarakat. Sekalipun diberikan wewenang penyelidikan, tidak terdapat penjelasan teknis terhadap

\footnotetext{
${ }^{19}$ Keputusan Presiden Nomor 134 Tahun 1999 tentang Kedudukan, Tugas, Fungsi, Susunan Organisasi, dan Tata Kerja Menteri Negara, Pasal 5 angka 10.

${ }^{20}$ Keputusan Presiden Republik Indonesia Nomor 50 Tahun 1993 tentang Komisi Nasional Hak Asasi Manusia, Bagian Menimbang.

${ }^{21}$ Ibid., Pasal 3.
} 
jangkauan bidang penyelidikan tersebut. Alhasil Komnas HAM tidak dapat menjalankan peran sebagai sebuah komisi yang diidealkan melaksanakan fungsi pengawasan ekstra parlementer kepada eksekutif. Padahal justru di bawah rezim Orde Baru-lah pelanggaran HAM yang dilaksanakan oleh birokrasi banyak terjadi. ${ }^{22}$

Pembentukan Komnas HAM versi Orde Baru ini juga merupakan contoh paripurna dari apa yang disebut Jimly Ashiddiqie sebagai fenomena "government by Keppres". Selama periode Orde Baru, banyak Keputusan Presiden yang lahir untuk mengatur hal-hal yang bersifat umum dan abstrak, maupun mengatur hal-hal yang bersifat individual dan kongkret. ${ }^{23}$ Padahal menurut TAP MPRS Nomor XX/MPRS/1966 tentang Memorandum DPR-GR Mengenai Sumber Tertib Hukum Republik Indonesia dan TataUrutan Peraturan Perundangan Republik Indonesia, sebuah Keppres seharusnya memuat pengaturan yang bersifat khusus (einmalig) untuk melaksanakan ketentuan konstitusi, TAP MPR dalam bidang eksekutif, maupun peraturan pemerintah. ${ }^{24}$ Posisi Keppres yang rendah dalam hierarki peraturan perundang-undangan Indonesia pada saat itu, menyebabkan lembaga negara yang lahir berdasarkan produk hukum tersebut secara otomatis menjadi lemah. ${ }^{25}$ Dari posisi ini, dan dengan mempertimbangkan catatan kejahatan kemanusiaan yang dilakukan rezim di masa lalu, maka penguatan kelembagaan Komnas HAM sesungguhnya mendesak untuk dilaksanakan.

Misi ini baru terwujud 6 tahun kemudian. Tak cukup dengan mengundangkan Keppres RANHAM, negara kemudian mengundangkan UU HAM. Di dalamnya, terdapat sejumlah pasal yang mengatur perihal kelembagaan Komnas HAM. Dari perspektif sumber hukum, dapat diartikan posisi Komnas HAM menjadi lebih kuat dan dapat meminimalisasi intervensi karena kelembagaannyadidasarkan pada undang-undang.

Berbeda dengan pengaturan di dalam Keppres Nomor 50 Tahun 1993, terjadi perluasan ruang lingkup fungsi Komnas HAM menurut UU HAM. Di bawah rezim UU HAM, Komnas HAM menjalankan fungsi pengkajian, penelitian, penyuluhan, pemantauan, dan mediasi tantang HAM. ${ }^{26}$ Apabila dibandingkan dengan periode sebelumnya, tampak jelas bahwa wewenang yang dibebankan oleh UU HAM kepada Komnas HAM semakin banyak dan kompleks. Pun,

\footnotetext{
${ }^{22}$ Lihat kembali sejumlah kasus pelanggaran HAM yang dilaksanakan oleh Orde Baru pada bab Pendahuluan.

23 Ashiddiqie, J, (Tanpa tahun), Perihal Undang-Undang (e-book), Jakarta: Tanpa Penerbit, hlm 116.

${ }^{24}$ Ketetapan MPRS Nomor XX/MPRS/1966 tentang Memorandum DPR-GR Mengenai Sumber Tertib Hukum Republik Indonesia dan TataUrutan Peraturan Perundangan Republik Indonesia, Bagian Penjelasan.

${ }^{25}$ Hierarki norma yang berlaku pada masa tersebut tercantum dalam TAP MPRS Nomor XX/MPRS/1966 yang terdiri atas (dari norma tertinggi ke nroma terendah): 1) Undang-Undang Dasar 1945, 2) TAP MPRS, 3) UndangUndang atau Peraturan Pemerintah Pengganti Undang-Undang, 4) Peraturan Pemerintah, 5) Keputusan Presiden, dan 6) Peraturan-peraturan pelaksanan lainnya. Ibid.

26 Undang-Undang Nomor 39 Tahun 1999 tentang Hak Asasi Manusia, Pasal 76 ayat (1).
} 
kedudukannya dalam proses birokratisasi urusan HAM di Indonesia semakin mapan.

Hubungan Kementerian Urusan HAM dengan Komnas HAM

Inisiatif mendirikan kementerian yang secara spesifik mengurus HAM segera setelah Reformasi dilaksanakan merupakan fenomena yang signifikan. Dalam posisinya sebagai perpanjangan tangan eksekutif, pembentukan pranata ini merupakan wujud upaya awal birokratisasi HAM oleh negara. Di sisi lain, Kementerian Urusan HAM juga dapat menjadi instrumen evaluasi internal atas elemen keterpenuhan HAM dalam setiap kebijakan pemerintah pasca reformasi. Eksistensinya memberikan pendekatan yang berbeda atas puluhan tahun peminggiran urusan HAM dalam perumusan kebijakan rezim, baik pada masa Orde Baru maupun Orde Lama.

Namun demikian, posisi Kementerian Urusan HAM masihlah rentan mengingat posisinya sebagai subordinat dari Presiden. Sebagai pelaksana tugas-tugas eksekutif, arah kebijakannya masihlah mungkin diintervensi. Pembebanan pemenuhan HAM hanya kepada salah satu lengan kekuasaan negara tanpa adanya pranata pengawas berpotensi kembali menjerumuskan birokrasi kepada pengabaian hak-hak sipil. Oleh karenanya, dibutuhkan suatu institusi pengawas eksternal yang menjalankan fungsi check and balances terhadap arah kebijakan HAM birokrasi. Di Indonesia, lembaga itu diwakili oleh Komnas HAM.

Dalam perspektif kelembagaan negara, Komnas HAM menduduki peran sebagai sebuah state auxiliary organ (lembaga negara penunjang). Kategori lembaga negara yang memiliki nama beragam ini (komisi, badan, lembaga, dan sebagainya), menurut Lembaga Admisitrasi Negara sebagaimana dikutip Evy Trisulo, diantaranya dapat dideskripsikan berdasarkan kedudukannya yang berada di luar pemerintah, bertanggung jawab kepada msayarakat, dan tidak dapat diintervensi. ${ }^{27}$ Lembaga penunjang melaksanakan fungsi pengawasan dan pemeriksaan atas satu ranah tertentu, maupun menjalankan tugas yang tidak dilaksanakan oleh lembaga pemerintah pada umumnya.

Menurut Angga Martandy, lembagalembaga negara penunjang umumnya lahir akibat krisis kepercayaan masyarakat atas lembaga-lemabaga negara yang telah hadir terlebih dahulu. Birokrasi tidak dapat memenuhi standar mutu pelayanan publik yang efektif dan efisien, sehingga dibutuhkan lembaga pengawas ekstra. $^{28}$ Sementara menurut Jimly, pembentukan lembaga

\footnotetext{
${ }^{27}$ Trisulo, Evy, (2012), Konfigurasi State Auxiliary Bodies dalam Sistem Pemerintahan Indonesia, Tesis Magister Universitas Indonesia, Jakarta, hlm 69.

${ }^{28}$ Prihantoro, AM, (2010), Eksistensi State Auxiliary Organs dalam Rangka Mewujudkan Good Governance di Indonesia: Studi Kelembagaan Terhadap Komisi Pemberantasan Korupsi, Skripsi Sarjana Universitas Sebelas Maret, Solo, hlm 22.
} 
penunjang yang bersifat otonom bertujuan untuk menjamin kelenturan pengelolaan kegiatan yang bersifat publik. ${ }^{29}$ Orientasinya pada pencapaian tujuan-tujuan publik menunjukkan keterlibatan dan relevansi lembaga-lembaga negara penunjang, termasuk Komnas HAM, dalam sistem birokrasi di Indonesia.

Lebih lanjut menurut Jimly, meskipun berstatus sebagai lembaga negara penunjang, Komnas HAM memiliki constitutional importance yang amat jelas. Di dalam setiap negara modern, jaminan atas HAM merupakan sesuatu yang tidak dapat diganggu gugat dan wajib dipenuhi. ${ }^{30}$ Posisinya yang berada di luar eksekutif memungkinkan Komnas HAM melakukan pengawasan secara independen terhadap birokrasi, sembari melaksanakan sebagian fungsi-fungsi birokrasi di bidang HAM. Dalam kerangka sistem birokrasi Indonesia, hal ini berseseuaian dengan cita-cita yang tercantumdalam Sila Kedua dalam Pancasila yang berbunyi, "Kemanusiaan yang Adil dan Beradab".

\section{KESIMPULAN}

Sepanjang periode Orde Lama dan Orde Baru, aspek-aspek penghormatan terhadap HAM sempat dipinggirkan dalam gerak birokrasi. Dalam konteks ini, pembentukan kementerian urusan HAM dan penguatan
Komnas HAM pasca reformasi merupakan manifestasi dari upaya kolaboratif antara politik dan hukum untuk membentuk sistem birokrasi Indonesia yang lebih humanis dan sesuai cita-cita Pancasila. Masing-masing lembaga memperoleh legitimasi dari dinamika politik di ruang publik yang lebih demokratis, sehingga menghasilkan produkproduk hukum pengatribusi wewenang kelembagaan yang lebih responsif. Antara kementerian negara urusan HAM dan Komnas HAM kemudian menjalankan prinsip check and balances dalam menjalankan perannya sebagai organ birokrasi Indonesia. Di satu sisi, kementerian negara urusan HAM merupakan perpanjangan tangan eksekutif untuk mengurus urusan HAM. Sebagai penyeimbang, Komnas HAM menjalankan peran sebagai state auxiliary bodies' guna mengawasi agar di dalam kinerjanya, pemerintah menghormati HAM secara penuh.

\section{DAFTAR PUSTAKA}

\section{BUKU}

Ashiddiqie, J. (Tanpa tahun). Perihal Undang-Undang (e-book). Jakarta: Tanpa Penerbit. . (2006). Perkembangan dan Konsolidasi Lembaga Negara Pasca Reformasi. Jakarta: Sekretariat Jenderal Mahkamah Konstitusi.

\footnotetext{
${ }^{29}$ Ashiddiqie, J, (2006), Perkembangan dan Konsolidasi Lembaga Negara Pasca Reformasi, Jakarta: Sekretariat Jenderal Mahkamah Konstitusi, hlm 13.

$30 \quad$ Ibid., hlm 244
} 
Dwiyanto, A. (2015). Reformasi Birokrasi Kontekstual. Yogyakarta: Gadjah Mada University Press.

Kasenda, P. Soeharto: Bagaimana Ia Bisa Melanggengkan Kekuasaan Selama 32 Tahun. Jakarta: Kompas.

MD, MM. (1999). Pergulatan Politik dan Hukum di Indonesia. Yogyakarta: Gama Media.

(2014). Politik Hukum di Indonesia. Jakarta: Rajawali Pers.

Nonet, P \& Selznick, P. (2009). Law and Society in Transition: Toward Responsive Law. London: Transaction Publisher.

Said, MM. (1961). Pedoman Untuk Melaksanakan Amanat Penderitaan Rakjat Djilid I. Surabaya: Penerbit Permata.

Shiraishi, SS. (2001). Pahlawan-pahlawan Belia: Keluarga Indonesia dalam Politik [Young Heroes: The Indonesian Family in Politics]. Diterjemahan oleh Tim Jakarta-Jakarta. Jakarta: Penerbit Nalar.

Subekti, VS. (2008). Menyusun Konstitusi Transisi: Pergulatan Kepentingan dan Pemikiran dalam Proses Perubahan UUD 1945. Jakarta: Rajawali Pers.

Thoha, M. (2014). Birokrasi dan Dinamika Kekuasaan. Jakarta: Kencana.

Tim Penyusun. (2010). Naskah Komprehensif Perubahan UndangUndang Dasar Negara Republik Indonesia Tahun 1945: Latar Belakang, Proses, dan Hasil Pembahasan 1999-2002,Buku VIII Warga Negara dan Penduduk, Hak Asasi Manusia, dan Agama. Jakarta: Sekretariat Jenderal dan Kepaniteraan Mahkamah Konstitusi Republik Indonesia.
PRESENTASI, KERTAS KERJA, SKRIPSI, DAN TESIS

Prihantoro, AM. (2010). Eksistensi State Auxiliary Organs dalam Rangka Mewujudkan Good Governance di Indonesia: Studi Kelembagaan Terhadap Komisi Pemberantasan Korupsi. Skripsi Sarjana Universitas Sebelas Maret, Solo.

Komisi Nasional Hak Asasi Manusia (Komnas HAM). (2012). Pernyataan Komnas HAM Tentang Hasil Penyelidikan Pelanggaran HAM yang Berat Peristiwa 1965-1966. Jakarta: Rangkuman Eksekutif tidak diterbitkan.

Hayati, T. (2012). Birokrasi dan Good Governance. Jakarta, Bahan Kuliah tidak diterbitkan.

Trisulo, E. (2012). Konfigurasi State Auxiliary Bodies dalam Sistem Pemerintahan Indonesia. Tesis Magister Universitas Indonesia. Jakarta.

\section{PERATURANPERUNDANG-UNDANGAN}

Undang-Undang Dasar 1945.

Ketetapan MPRS Nomor XX/MPRS/1966 Tahun 1966 tentang Memorandum DPR-GR Mengenai Sumber Tertib Hukum Republik Indonesia dan TataUrutan Peraturan Perundangan Republik Indonesia.

Undang-Undang Nomor 39 Tahun 1999 tentang Hak Asasi Manusia.

Keputusan Presiden Republik Indonesia Nomor 50 Tahun 1993 tentang Komisi Nasional Hak Asasi Manusia.

Keputusan Presiden Nomor 134 Tahun 1999 tentang Kedudukan, Tugas, Fungsi, Susunan Organisasi, dan Tata Kerja Menteri Negara.

\section{INTERNET}

Aghnia A. Beda Jurus Korupsi Era Soeharto dan Reformasi. Diakses 28 Februari 
134 Yurispruden Volume 2, Nomor 2, Juni 2019, Halaman 119-134

2017.

http://www.cnnindonesia.com/nasional/ 20150521153708-74-54824/beda-

jurus-korupsi-era-soeharto-danreformasi/.

Elsam. Dokumentasi Pelanggaran HAM di Indonesia: Peristiwa Talangsari Lampung 1989. Diakses pada 26 Februari 2017. http://dokumentasi.elsam.or.id/mobile/r eports/view/296?c=66\&p=1.

Dokumentasi Pelanggaran HAM: Peristiwa Penghilangan Paksa Tahun 1997-1998. Diakses pada 26 Februari 2017.

http://dokumentasi.elsam.or.id/reports/v iew/305.

LBH Pers Padang. Jaminan Kebebasan Pers Indonesia. Diakses 26 Februari 2017. http://lbhperspadang.org/jaminankebebasan-pers-indonesia/. 